Published as: 'Swimming against the current? Rolf Lappert's Nach Hause schwimmen', in: Figurationen - Gender/Literatur/Kultur, 01/2010, ed. by Barbara Naumann and Lorena Silos Ribas, Köln: Böhlau, pp.113-127.

See: http://www.degruyter.com/view/j/figurationen.2010.11.issue-

1/figurationen.2010.11.1.113/figurationen.2010.11.1.113.xml?format=INT

\title{
Swimming Against the Current? Rolf Lappert's Nach Hause schwimmen
}

\section{Valerie Heffernan}

Rolf Lappert's 2007 novel Nach Hause schwimmen [Swimming Home], seems on the surface to be anything but a Swiss novel. Set in part in rural Ireland and in part in the United States and with a brief interlude in Sweden, it tells the story of „Will McDermott, alias Wilbur Sandberg, verhinderter Selbstmörder mit partiellem Gedächtnisverlust, zwanghafter Trinkhalmbenutzer und traumatageschädigter Nichtschwimmer". ${ }^{1}$ Wilbur's story has a wider resonance, as indicated by Anja Hirsch, who proclaims: „Nach Hause schwimmen' ist nicht nur Wilburs Geschichte, sondern Familien-, Irland-, Amerika-Roman. "2 Lappert’s novel draws on established images of Ireland and America and on cultural representations of the sea and uses these as a springboard to explore issues of belonging and separation, integration and exclusion.

It is ironic that it is precisely the fact that Rolf Lappert opts to set his texts outside of Switzerland that marks him as a Swiss writer. In Lappert's decision both to make a new life for himself far away from the mountains of Switzerland - the writer lives in County Kerry in the south-west of Ireland - and to set his texts far away from his alpine birthplace, he seems to exemplify everything that Paul Nizon suggested to be typical of Swiss artists. In his much discussed essay Diskurs in der Enge of 1970, Nizon describes the narrowness and restrictiveness of the

\footnotetext{
${ }^{1}$ Lappert (2008), 288.

2 Hirsch (2008).
} 
Swiss cultural landscape, which constrains Swiss artists and writers and prevents them from producing anything of real artistic value. Controversially, Nizon argued that the only option for a Swiss artist is to escape to foreign lands. He points to many examples of writers, including Robert Walser, Friedrich Glauser and Albin Zollinger, who liberated themselves from the confines they experienced in their alpine homeland and sought to spread their wings abroad. ${ }^{3}$ Indeed, the fact that Nizon himself settled in Paris shortly after publishing his essay and spent the rest of his life there can be seen as proof of the productivity of the Swiss writer on foreign soil.

However, despite his similarity to other Swiss writers, it seems that in many respects, Lappert has created a unique text. It has been noted by many reviewers that Nach Hause schwimmen can be seen as a modern-day Bildungsroman, written in an era when writers no longer write Bildungsromane. ${ }^{4}$ Its protagonist, Wilbur Sandberg, is an unlikely hero; as a man of unusually short stature, a gifted musician and a loner, Wilbur seems to be an exception on all fronts. Despite various attempts to belong in school, in his foster home, in a remand home, and later in the hotel for old men in New York - Wilbur inevitably stands out. He is an outsider who is both difficult to categorise and impossible to forget. The reader is left with the impression that Wilbur is simply unable to deal with the floodtide of life; he is swept along in its current, overwhelmed by its power.

In its construction, Nach Hause schwimmen confronts the reader with an unusual narrative situation. The novel presents two narrative viewpoints and two temporal situations, both of which centre around Wilbur. In the first person, Wilbur tells the story of his recovery from an attempted suicide by drowning; alongside this, we are told in the third person of Wilbur's childhood in Ireland and the events leading up to his suicide attempt on his twentieth birthday. These two narrative strands are woven together and play off each other, a strategy which is both disorientating and fascinating for the reader; as Christine Richard remarks: „Wo beide Erzählbewegungen sich treffen, entsteht ein Strudel, und der Lesende gerät ins

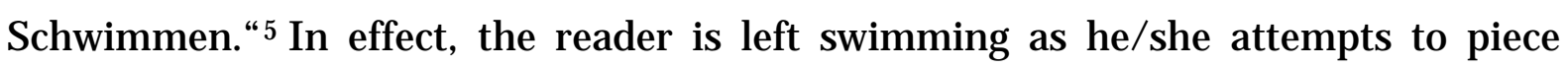
together the story of Will McDermott, alias Wilbur Sandberg.

\footnotetext{
${ }^{3}$ Cf. Nizon (1970).

${ }^{4}$ Cf. van Rossum (2008); Graf (2008); Pfister (2008).

${ }^{5}$ Richard (2008).
} 


\section{Lappert's Irish J ournal}

By choosing Ireland as the background for his story of Wilbur's childhood, Rolf Lappert follows the way that has been paved by many Swiss writers before him, including Claudia Storz, Margrit Baur, Gerold Späth, Hansjörg Schertenleib and Gabrielle Alioth. Lappert connects his decision to set his novel in part in Ireland with his fondness for the country: „Ich wollte immer eine Geschichte schreiben, die teilweise in Irland spielt, weil mir Land und Leute so gut gefallen. "6 However, he is equally clear that the text itself should not be limited by the location: „Ich [...] liebe epische Storys, die in weiten Landschaften spielen, sozusagen auf großer Bühne. “7

However, the Ireland depicted in Nach Hause schwimmen is not the Ireland of the 1980s and 90s in any real sense; in particular, the Ireland of Lappert's novel bears no relation to the modern, forward-moving, fast paced land of economic boom and Celtic Tiger. The narrative does not focus on the cities or towns of Ireland; apart from the odd trip to Letterkenny and one memorable visit to Dublin, the majority of the action takes place in the area around Eamon McDermott's family home near Fanad Head on the north-west coast of Ireland. Indeed, it is doubtful whether Lappert could have chosen a more remote spot for his narrative; when Wilbur arrives in Ireland from America, he and his grandfather must first take a train westwards to Sligo, then travel north for several hours in a bus to the tiny village of Kindrum and from there make their way even further north to the tip of the Fanad peninsula, where the McDermott farm is situated. This is the area where Eamon grew up, the bleak and lonely landscape of his youth. It is the land that Eamon and his wife retreat to after their only daughter Maureen leaves them to begin a new life in America. It is the house which becomes a home for their orphaned grandson Wilbur after his mother dies in childbirth and his Swedish father Lennard Sandberg, overwhelmed by his grief, abandons him at Saint Francis Hospital in Philadelphia. This house becomes the locus of Wilbur's love for his grandmother Orla and the haven to which he returns many times to find solace.

The geographical location of this house - on the cliffs at the furthermost limit of the island at the farthest edge of Europe - reflects the peripheral position of the McDermott family at the edge of the community. Although they are known to everyone in the area, they maintain a certain distance from the other townsfolk. In a village where the

\footnotetext{
${ }^{6}$ Rausch (2009).

${ }^{7}$ Rausch (2009).
} 
boys are named Conor or Seán, Liam or Colm, like their fathers before them, Wilbur Sandberg is immediately marked as an outsider by his name. In addition, in a place and time where the nuclear family is very much the norm, Wilbur's atypical family situation further separates him from the other children and reinforces his difference. Orla's very public and ultimately futile efforts to convince the authorities to allow her to home-school her grandson instead of sending him to the local primary school and her subsequent decision to drive him to school instead of allowing him to take the school bus with the other children serve only to cement Wilbur's segregation. The small-town Irish Catholic community of Kindrum view Orla and Eamon's solitary lifestyle with wariness and suspicion, and their isolated position on Fanad Head both brings about and facilitates their separation from the rest of the community.

As one might expect for an island such as Ireland with roughly $7500 \mathrm{~km}$ of coastline and with no spot more than $100 \mathrm{~km}$ from the coast ${ }^{8}$, the sea is vital to the internal life and external image of the country. In Lappert's narrative, too, the sea plays a central role. It is the source of income for many in the community; for generations, the local population has been involved in the fishing industry, and countless locals have lived and died by the water. In this, the sea is also a constant threat, and many deliberately seek out other professions to avoid its dangers. Orla's father, a fisherman, pays to have her educated abroad in the hope that she will avoid having to depend on the sea for a living. However, Orla is drawn home to the Irish coast, where she uses her knowledge of foreign languages to sell her father's fish to the tourists. Eamon's strict father, Aidan, who is emphatically „,kein Mann der See“9, has seen too many lose their lives in its service; he prefers to breed sheep, like his father before him. For Eamon, the sea only emphasises his sense of captivity and the inertia he feels in this life:

Eamon wollte nicht Schafe züchten wie sein Vater und sein Großvater. Er wollte nichts mit den dummen, stinkenden Tieren zu tun haben, wollte ihnen nicht im Nebel nachtrotten, nicht mit ihnen über Hügel stapfen oder mit ihnen unter Büschen hocken, vergeblich auf das Ende des Regens wartend. Er hasste die Gerichte, die mit ihrem Fleisch gekocht wurden, hasste die Pullover, deren fettige Wolle ihm die Luft zum Atmen nahm, und er hasste ihr Blöken, das einfältig und klagend war wie das Jammern der alten Weiber vor der Kirche. Er wollte nicht bis ans Ende seiner Tage unter diesen Kreaturen ausharren und irgendwann, genährt von ihrem Fett und eingehüllt in ihr Haar, zu ihresgleichen werden. Nach New York

\footnotetext{
8 Figures according to Nairn (2007).
}

${ }^{9}$ Lappert (2008), 41. 
wollte er, über den Atlantik in ein neues Leben, am liebsten mit dem nächsten Schiff. 10

In these lines as elsewhere, the sea is a source of longing - longing for what lies on the other side of the water and for a life beyond the small Donegal town. Indeed, it is noteworthy how many times in the narrative the characters, particularly Eamon, Orla and Wilbur, are presented in the same position: standing on the beach or sitting on the cliffs, looking out over the sea and dreaming of what lies beyond it, of what might have been or what might still be.

If it is the sea that imprisons Eamon in this hell, it is also the sea that offers him release from his captivity, when it delivers into his care a dying sailor who has almost drowned in a shipwreck. Crucially, this sailor is found to have a bag of jewels and gold nuggets, and Eamon does not hesitate: He robs the man's treasures even before he has died. It is paradoxical that although his ill-gotten wealth affords Eamon the opportunity to cross the water and return to Ireland as a rich man, he uses the money to build a house on his father's land - that very land he sold his soul to escape.

There is no overlooking the fact that Nach Hause schwimmen reproduces long established literary clichés about Ireland. The clichéd vision of the country that emerges from Lappert's narrative bears a strong resemblance to the image of the Grüne Insel presented in German-language travel guides and glossy coffee-table books, in which rocky seashores, rolling green fields and remote cliffs dominate the landscape and the only living things to be seen for miles are sheep, cows and wild horses. ${ }^{11}$ However, these images are by no means new. Early travellers to Ireland were struck by its rugged coast, its low but rocky mountains and the variations in its landscape. ${ }^{12}$ The sea was a source of fascination for many, and as far back as the midnineteenth century, German travel writers referred to the powerful threat of the sea, which they depicted as "herzlos" and „verrätherisch“. ${ }^{13}$ In addition, the idea that the Irish are powerfully connected to nature and to the land - in contrast to the continental Europeans - is prevalent in twentieth century writing on Ireland. ${ }^{14}$

However, Heinrich Böll's Irisches Tagebuch (1957) is still the text which has had the strongest influence on the image of Ireland in the German-speaking world. ${ }^{15}$ Böll's journal recounts his impressions from his first visit to Ireland with his family in 1954. The fact that he spent the majority of his time in the West and on Achill Island, off the coast

\footnotetext{
${ }^{10}$ Lappert (2008), $35 \mathrm{f}$.

${ }^{11}$ Cf. Dohmen (1994), 180. A glance at the cover of the Hanser hardback edition of Lappert's Nach Hause schwimmen, with its picture of a white horse on a rocky sea-shore, serves to illustrate the marketing value of such images.

12 Cf. Sebastian Münster (1578), quoted in Oehlke (1992), 128.

${ }^{13}$ Carl Adolf Helferreich (1858), quoted in Oehlke (1992), 147.

${ }^{14}$ Cf. Dohmen (1994), 179.

${ }^{15}$ For an overview of the reception of Böll's Irisches Tagebuch and its impact in Germany, see Holfter (1996), 139-141 and 147-154.
} 
of Mayo, clearly shapes his picture of Ireland and the Irish people as a nation of teadrinkers and storytellers living in remote, abandoned villages with streets that belong to children and cows. Böll's narrative was received enthusiastically in Germany, and it reinforced an image of Ireland as a land apart from the rest of Europe, with a different way of life and a different way of looking at the world. The fact that Böll penned his narrative at a time when Germany was in the throes of an economic miracle which had an impact on all aspects of domestic life and changed the face of the country is by no means insignificant. For this reason, Marcel Reich-Ranicki classed Böll's Irisches Tagebuch as "ein verstecktes Deutschlandbuch“, which said more about Böll's negative feelings vis-àvis his homeland than about the Ireland he encountered. 16

Lappert's depiction of Ireland reveals similar tendencies towards clichéd images, and we might speculate that the writer is playing on images that have already become established in German-language literature featuring the island. Like Böll, he gives the picture of a predominantly rural Ireland: a universe of small towns and close-knit communities in which the outsider sticks out like a sore thumb. The influence of the church is palpable, and the population is racked by the pain of emigration. The Ireland depicted in Nach Hause schwimmen also embodies something of the magical otherness that Böll portrays in his Irisches Tagebuch: The Irish are presented as dreamers and storytellers, drinkers and scoundrels. The fact that this aspect of the book speaks to a German-speaking audience is indicated by the enthusiastic words of one reviewer:

In diesem irischen Teil kommt die Erzählkunst des Autors am besten zur Geltung. Grandios fängt er die Landschaft ein, findet immer neue Bilder für das Licht, den Himmel und die Wolken, und seine irischen Figuren sind prall von Leben, sogar wenn sie nur kurz mitspielen und mit wenigen Sätzen charakterisiert sind. ${ }^{17}$

If Lappert's image of Ireland is one which relies on cultural and literary clichés, then this aspect of the novel certainly did not seem to trouble his reviewers.

\section{Streets Paved with Gold: Lappert's America}

Although Nach Hause schwimmen is set partly in Ireland, Rolf Lappert clearly identifies the text more as an American novel. This is the third volume of what Lappert terms his „Amerikanische Trilogie"18; the two other novels, Der Himmel der perfekten Poeten (1994) and Die Gesänge der

\footnotetext{
${ }^{16}$ Reich-Ranicki (1963), 135.

17 Pfister (2008).

${ }^{18}$ Steiner (2009).
} 
Verlierer (1995) also take place in the United States. In some respects, however, the America depicted in Nach Hause schwimmen represents a new departure for the author, since it is set in the metropolis of New York; whereas Lappert's earlier American novels were set in the Arizona desert and rural America.

America appears in two forms in the narrative: It is the setting for what is chronologically the second strand of the novel, which begins in 2000 with Wilbur's recovery from his brush with death by drowning; but it is also a projection screen for the dreams and hopes of the characters in the first strand of the narrative, which encompasses Wilbur's childhood and youth in Ireland. Even in the chapters that are set in Ireland, continuous references are made to America and the world of opportunities it represents. We thus experience two forms of America; one that is very clearly a construct and one that is presented as Wilbur's reality, but which in some ways comes across as just as artificial as the dream-like version of America that enthrals the young people of Ireland.

For the Irish in Nach Hause schwimmen, America is constantly seen as the goal, the land of plenty that lies just beyond the water. Indeed, Ireland has a long history of emigration to America, and this is reflected in Lappert's novel. Like the Irish families that Böll encounters in his Irisches Tagebuch, who lose half of their children in the American diaspora ${ }^{19}$, the families in Lappert's narrative are also faced with the grim reality of a country unable to support their children. Yet America also represents an escape for many of the young people, who look with longing towards the land beyond the water. The America envisioned by the young Irish, who dream of starting a new life there, is the antithesis of the Ireland that makes up their dreary reality. For example, in contrast to the rural landscapes that entrap him, Eamon dreams of living amongst the skyscrapers of New York. A generation later, his daughter Maureen dreams of a life of freedom and anonymity, a refuge from the undivided attention of her parents. The fact that after her emigration, she managed to conceal both her marriage and pregnancy from her parents reinforces the idea that in America, one can disappear into anonymity.

The America that emerges in the earlier chapters of the narrative is very clearly a reflection of the hopes, dreams and desires of the young Irish depicted in the novel, and this is emphasised in the description of that land. America is a land of liberty and opportunity, with untold wealth just waiting for those who dare to make the crossing. The cliché of American streets paved with gold is reflected almost to the point of

${ }^{19}$ Böll (1957), 98, 100, 116 f. 
parody in the way in which Eamon rewrites history and claims to make his fortune there. Armed with the treasure he has stolen from the dying sailor, he makes his way to Colorado:

J eden Tag holte er ein paar Goldstücke aus dem Lederkoffer, [...] legte sie zwischen die Steine in den Fluss, hob sie auf, trocknete sie ab und steckte sie in einen Beutel. Das wiederholte er so oft, bis er tatsächlich glaubte, die Nuggets im klaren Wasser gefunden zu haben. ${ }^{20}$

The artificiality of Eamon's private gold rush serves to reinforce the constructed nature of the American Dream that engenders such longing in the youth of Ireland. In addition, the fact that the Irish at home blindly believe the idea of a young man going to America to return just a few brief months later as a rich man also illustrates the extent to which the vision of the United States as a land of unlimited opportunities has gained general acceptance.

The Irish are not the only emigrants to America, as is emphasised in Lappert's account of Maureen's experiences in Philadelphia. His portrayal of the relationship between the Irish beauty Maureen and the Swedish immigrant Lennard Arne Sandberg highlights the universal attraction of the American Dream. Like Maureen, Lennard leaves his small town in the North of Sweden and his distraught parents to begin a new life in America. In Philadelphia, he finds the success and prosperity he seeks: „Alles lief wunderbar, der J unge aus Nora träumte den amerikanischen Traum mit offenen Augen, die Welt gehörte ihm. "21 His marriage to Maureen is the icing on the cake, and their plans for a happy life together mirror those of millions of other emigrants who hope to make the United States their home. Unfortunately, her death after giving birth to their longed-for first child brings and end to all of his hopes and shatters his American Dream once and for all. Furthermore, his unwillingness or inability to take care of his baby son after Maureen's death robs Wilbur of a father and sets in motion Wilbur's lifelong search for his roots, for a family and a place where he truly belongs.

Wilbur's own experiences in the United States in the later chapters of the novel also draw attention to America's reputation as a haven for immigrants. Indeed, one only need look at the names of the characters Wilbur encounters to gain a picture of the range of nationalities represented: Melvin Rosenkranz, Roger Willett, Dr. Ruud Vermeer, Alice Krugshank, Nathalie Kerkowski, Leroy Perkins, Gustavo Ovetti, Enrique, Rodrigo, Elwood, Leonidas, Mazursky, Winston. The characters' names mark a strong contrast to rural Ireland, which in turn raises the complex

\footnotetext{
${ }^{20}$ Lappert (2008), 50.
}

${ }^{21}$ Lappert (2008), 269. 
issue of segregation and integration. In his small Irish town, Wilbur immediately stood out as different due to his foreign-sounding name; in this classic melting pot, the name Wilbur Sandberg appears no more unusual than that of any other person. In this respect, America does seem to offer the desired freedom and anonymity for Wilbur.

Critics have often highlighted the regularity with which Swiss writers have opted to set their literary texts in America, and in this respect, Lappert is no exception. ${ }^{22}$ Like Lappert, many other Swiss authors also employ depictions of America to challenge the idea of the American Dream: as the title of a Swiss anthology on America suggests, „The Dream Never Becomes Reality“. ${ }^{23}$ It is noteworthy that Swiss writers, like their German counterparts, often pay attention to the urban United States rather than to rural or provincial life. The skyscrapers of New York seem to offer a particularly attractive backdrop for Swiss narratives, ${ }^{24}$ and Lappert is no exception. In contrast to his depiction of Ireland, which focuses on the rural and remote landscapes of the North West, the American chapters of Nach Hause schwimmen are set in New York. Wilbur's New York is the quintessential sprawling metropolis, where the individual can get lost. When Wilbur plans to go missing, it proves very easy to hide out in a cheap hotel. He is all too familiar with the many indistinguishable bars that pepper the city landscape. Moreover, he spends months trawling the streets, handing out flyers and looking for any trace of his father, without success. New York, it seems, is a city where a person can disappear if he so chooses.

Many contemporary Swiss authors such as Peter Stamm allow their writing to be influenced by American writers ${ }^{25}$, and here also, Lappert can be seen to reflect trends in Swiss writing. As critics such as Guido Graf have suggested, Nach Hause schwimmen is reminiscent of „das beste der amerikanischen Erzähltradition“. ${ }^{26}$ In particular the black humour evident in such tragicomic scenes as Wilbur's failed attempt to drown himself at Coney Island on his twentieth birthday, or the macabre twist of fate that brings about Orla's death - she crashes her sky-blue Nissan Sunny trying to avoid a horse that is spooked by the gunshot when Conor Finnerty tries to kill his father - call to mind the cunning prose of J ohn Irving. In fact, the figure of Wilbur resembles Irving's Owen Meany to such an extent that he appears to be his literary twin. ${ }^{27}$ Clearly, Lappert's writing has also been influenced by literary models he was confronted with during his years in America. In this respect, Nach Hause schwimmen would seem to connect the author to a wider

\footnotetext{
${ }^{22}$ Cf. Sabalius (1997) for a more detailed survey of Swiss texts on America.

${ }^{23}$ Schnauber/Sabalius/ Stimpson (1995).

${ }^{24}$ Sabalius (1997), 18 f. Cf. also Bauschinger (1975).

${ }^{25}$ Cf. Spiegel (2000) and Reinacher (2003), 20.

${ }^{26}$ Graf (2008). Cf. also Steiner (2009).

${ }^{27}$ Cf. Irving (1989). Interestingly, Rolf Lappert prefers to draw a distinction between his protagonist and J ohn Irving's; he emphasises that unlike Owen Meany, Wilbur does continue to grow throughout the narrative, so that rather than being „kleinwüchsig“, he is merely „körperlich etwas zurückgeblieben“. In: Rausch (2009).
} 
tradition in Swiss writing. By setting his novel in part in America and following the example set by the great American storytellers, Lappert reflects what many other Swiss writers have done and continue to do in their writing.

\section{Swimming Between Two Cultures}

Given the huge expanse of water that separates Wilbur's two homes, Ireland and the United States, it is no surprise that water should play such a dominant role in this narrative. It seems noteworthy that the novel both opens and closes with images of Wilbur submerged in water, subject to the powerful sea. Indeed, Lappert emphasises that the novel was inspired by the image of a young man falling from a jetty into the water: „Dieses Bild hat mich jahrelang begleitet, und irgendwann wusste ich, dass es die erste Szene eines Romans war. "28 In some respect, it might even be argued that Nach Hause schwimmen is the story of Wilbur's complex and at times challenging relationship with the sea.

The Swiss literary critic Peter von Matt identifies the sea as one of the most important motifs in Swiss literature; he argues that it appears constantly as „das imaginäre Andere der Schweiz, das, wohin man immerzu aufbricht“. ${ }^{29}$ For Swiss writers living in Ireland such as Gabrielle Alioth and Rolf Lappert, the sea serves as a constant reminder of the difference between their homeland and the land they have chosen to make their home. Alioth refers to Ireland as „die Verkörperung des ,Anderen' der Schweiz"30, while Lappert describes his relationship to the sea as follows: „Ich glaube, wir Schweizer haben eine besondere Affinität zum Meer, weil wir in einem Binnenland leben. Die Schweiz ist zwar auch eine Insel, aber eben eine der etwas anderen Art. “31

In recent years, many studies have contributed to our understanding of the significance and the vital role of water in culture and society. Hartmut Böhme's pioneering study Kulturgeschichte des Wassers accentuates the pronounced physical and spiritual bond that connects humankind to the sea: „das Meer [wird] als Inbegriff der lebendigen Natur entwickelt [...], Ursprung und Klammer des Lebens, gewaltiger Organismus, der im produktiven Kreislauf von Geburt und Tod die Matrix des Lebendigen darstellt." 32 Water is intimately connected with the life-cycle; it is both the origin and source of life on the one hand and a threat to life on the other. Elsewhere, Böhme elaborates on the elasticity and all-pervasiveness of this element: „Das Wasser strömt durch alles

\footnotetext{
${ }^{28}$ Rausch (2009).

${ }^{29}$ von Matt (2001), 57.

30 Donovan (2008), 287.

${ }^{31}$ Rausch (2009).

32 Böhme (1988), 35.
} 
hindurch - durch unsere Körper, die Industriesysteme, die Kanalisation, die Pflanzen, die Länder, es steigt auf als Wolken, fällt als Regen herab und fließt von den Bergen ins Meer". 33 More recent analyses seek to explore the cultural significance of water in the contemporary era, when the relationship between man and his natural environment has come under increasing threat from hitherto unforeseen levels of industrialisation and urbanisation. 34

In many literary texts, the sea is presented as a source of positive energy; the water, associated with life, with renewal and even rebirth, is the place where the individual can find peace and harmony. Axel Goodbody posits this as a return to a pre-modern, more natural state of being: „das Eintauchen im Wasser [versinnbildlicht] die Wiedergewinnung einer ursprünglichen Einheit mit der Natur“. ${ }^{35}$ Many contemporary authors such as Szusza Bánks, Katharina Hacker, Hugo Loetscher, Arnold Stadler and perhaps most notably J ohn von Düffel present swimming as an activity that offers respite from life's troubles and an opportunity to reconnect with nature. ${ }^{36}$ It is also significant that swimming is a distinctively individual activity. As Andrea Bartl points out: „Der Schwimmer entfernt sich innerlich von seinem Alltagsleben, seinen Freunden, seiner Familie. [...] Das bedeutet vom Standpunkt der Kultur und menschlichen Gesellschaft her gesehen die totale Isolation, vom Standpunkt der Natur gesehen die totale Integration." ${ }^{77}$ Thus, in many of these writers' works, swimming is associated with the borderline; with movement from one sphere of existence to another and with processes of integration and assimilation. In von Düffel's work, it is also closely connected with processing memories and with writing. 38

In this respect, Rolf Lappert seems to be swimming against the current that moves other writers of his generation. Indeed, it might at first seem ironic that he has opted to call his novel Nach Hause schwimmen, given that its protagonist is a selfprofessed and stubborn non-swimmer. In Lappert's novel, the sea is not depicted as a benign force. Against the traditional iconography of water as a symbol of life, the sea in Lappert's narrative becomes a threatening force that is all too often associated with death by drowning. Wilbur's simultaneous fascination with and fear of the sea are articulated most clearly in his childhood fantasies about the mysteries it conceals: Wilbur [...] ging nicht gerne an den Strand. Das Meer als abstrakte Masse, als weite blaue Fläche faszinierte ihn, auch der Gedanke, dass dahinter Amerika lag. Aber den Geruch fand er eklig und das monotone

\footnotetext{
33 Böhme (2000), 17.

${ }^{34}$ Cf. Goodbody/Wanning (2008).

35 Goodbody (2008), 13.

${ }^{36}$ Cf. Bartl (2009).

37 Bartl (2009), 485.

${ }^{38}$ Cf. Barkhoff (2003), 254.
} 
Geräusch der anrollenden Wellen machte ihn nervös. Wenn er die farbigen Illustrationen in seinem Tieratlas betrachtete, erfasste ihn ein Schaudern, sogar harmlose Kugelfische kamen ihm vor wie kleine Monster, die nur darauf warteten, dass er seinen Zeh in ihre Welt streckte. Er verstand die Menschen nicht, die darin schwammen, und Taucher hielt er für komplett verrückt, auch wenn er insgeheim ihren Mut bewunderte. 39

From a young age, Wilbur is a reluctant swimmer. Despite the zealous efforts of Fintan Taggart, a local man who lost his father in a boating accident and subsequently made it his mission in life to raise money to build Donegal's first swimming pool and to teach the children of the area how to swim, Wilbur proves to be the only child that is immune to the swimming teacher's almost religious fervour. Taggart's well-meaning attempts to teach him to swim serve only to provoke terror and panic in Wilbur:

Erst in dem Becken, an dessen Boden die Namen der Ertrunkenen durch einen Film aus milchigem Wasser schimmerten, entwickelte Wilbur Todesangst. Unter dem Brüllen des Lehrers und dem J ohlen der Mitschüler schaufelte er mit den Armen und schlug mit den Beinen, ein mickriges Hündchen, der schwächste Welpe aus dem Wurf, den man ertränkte. ${ }^{40}$

Taggart's swimming pool, a monument to all of the local people who have lost their lives to the sea, proves too much for Wilbur; as if overwhelmed by the din of the other swimmers and pulled down by the undercurrent of those many drowned souls, he is unable to resist the power of the water.

Wilbur's phobia of the water is a fear that accompanies him throughout his life; his fear is so severe that even simple activities such as showering or drinking from a cup are sources of great anxiety to him. This extreme aversion to water marks him as a man who has lost touch with nature and thus with himself. However, he must find a way across the water - both physically and figuratively - if he is to retrace his steps, find his father and come to some understanding of his origins, his identity. He must learn to integrate, rather than to remain forever an outsider; to open up to his environment, rather than isolating himself from the people he encounters along the way. In his long journey towards maturity, Wilbur must learn to swim instead of simply being swept with the current.

Wilbur does eventually come to find a new understanding and acceptance of himself, though contrary to his expectations, it does not come through finding his father. Wilbur's memory loss after his suicide 
attempt enables him in some way to wipe the slate clean and rewrite his own personal story. By submerging himself in his past, Wilbur begins to forge a new identity for himself - one that is no longer concerned with the failures of his father and the deficiencies of his childhood and youth. His connectedness with the people who help him in the aftermath of his suicide, and in particular his burgeoning relationship with Aimee, the American girl who helped him through his recovery, help him to focus instead on the possibilities of the future.

The closing scene of the narrative, which shows Wilbur back in Ireland swimming in the sea, can thus be read as the culmination of Wilbur's longjourney an odyssey which made it possible for him to find orientation in a fluid, unpredictable world. It is also noteworthy that it is only in the concluding chapters that the two different narrative strands come together; thus the reader also gains a new confidence, as the two streams of the narrative no longer seem so murky and disorienting. It is significant that Wilbur is joined in the water by Aimee, the American girl who had helped him after his suicide attempt. Wilbur has survived the water and he has taken control of his own life. He is by no means a masterful swimmer: „Ich schwimme wie ein Hund, eher schlechter“, he tells us. „Aber ich schwimme. ${ }^{* 41}$

\section{Wilbur's Long Swim Home}

The title of Lappert's Nach Hause schwimmen, however, remains confusing since it is not entirely clear whether Wilbur considers Ireland or America as his home. Then again, the text is not about a particular location but rather about a search for a place in a community, a part in the bigger picture. The novel reflects Wilbur's quest to fit in, and in doing so, it raises deeper questions about identity, community and belonging. It plays with the idea of the borderline, the murky waters between cultures and between communities.

Furthermore, the unusual narrative perspective allows us to occupy both the internal and external positions simultaneously; we are both observers of the events which befall Will McDermott alias Wilbur Sandberg and we are active participants in those events. We follow him to the backwaters of Donegal and to the metropolis of New York in his search for a family and an identity; we also accompany him back into the past, through the present and into the future. We explore the geographical borders that segregate the individual from the wider com-

${ }^{41}$ Lappert (2008), 544. 
munity and enable him to become part of the collective, and we cross the temporal borders that allow him access to the memories of the past and the dreams of the future. We swim with Wilbur in the sea of his confusion; and with him, we emerge from these murky waters at the end of his odyssey.

\section{Bibliography}

Barkhoff, Jürgen (2003): „Naturgefühle - ,Vom Wasser““. In: Anne Fuchs/ Sabine Strümper-Krobb (eds.): Sentimente, Gefühle, Empfindungen. Zur Geschichte und Literatur des Affektiven von 1770 bis heute. Würzburg: Königshausen \& Neumann, 243-254.

Bartl, Andrea (2009): „Der Wechsel von einem vertrauten Element in das Andere, Fremde: Das Motiv des Schwimmens in der deutschen Gegenwartsliteratur". In: German Life and Letters 62/ 4, 482-495.

Bauschinger, Sigrid (1975): „Mythos Manhattan. Die Faszination einer Stadt“. In: Sigrid Bauschinger/Horst Denkler/Wilfried Malsch (eds.): Amerika in der deutschen Literatur. Neue Welt - Nordamerika - USA. Stuttgart: Reclam, 382397.

Böhme, Hartmut (1988): „Umriß einer Kulturgeschichte des Wassers. Ein Einleitung". In: id. (ed.): Kulturgeschichte des Wassers. Frankfurt a. M.: Suhrkamp, 7-42.

Böhme, Hartmut (2000): „Anthropologie der vier Elemente“. In: Bernd Busch/ Larissa Förster (eds.): Wasser. Köln: Wienand, 17-37.

Böll, Heinrich (1957): Irisches Tagebuch. München: dtv, 1997.

Dohmen, Doris (1994): Das deutsche Irlandbild. Imagologische Untersuchungen zur Darstellung Irlands und der Iren in der deutschsprachigen Literatur. Amsterdam: Rodopi (=Studia imagologica 6).

Donovan, Siobhán (2008): „Der romantische Sog des Wassers, des weiblichen Elements. $\mathrm{Zu}$ Gabrielle Alioths Irland-Roman Die Arche der Frauen“. In: Goodbody/ Wanning (2008), 285-300.

Goodbody, Axel (2008): „Wasserkultur: Kulturelle Dimensionen der ökologischen Wende im Umgang mit dem Wasser und die Leistung der literarischen Imagination“. In: Goodbody/ Wanning (2008), 9-21.

Goodbody, Axel/Wanning, Berbeli, eds. (2008): Wasser - Kultur - Ökologie. Beiträge zum Wandel im Umgang mit dem Wasser und zu seiner literarischen Imagination. Göttingen: V\&R unipress.

Graf, Guido (2008): „Sehnsucht vom anderen Leben“. In: Frankfurter Rundschau 218, 17. 09. 2008, 30.

Hirsch, Anja (2008): „Es ist nicht schön, allein zu sein“, in: Frankfurter Allgemeine Zeitung 189, 14. 08. 2008, 40.

Holfter, Gisela (1996): Erlebnis Irland. Deutsche Reiseberichte über Irland im zwanzigsten J ahrhundert. Trier: Wissenschaftlicher Verlag Trier.

Irving J ohn (1989): A Prayer for Owen Meany. New York: Morrow.

Lappert, Rolf (2008): Nach Hause schwimmen. München: Hanser.

Matt, Peter von (2001): „Bilderkult und Bildersturm. Eine Zeitreise durch die literarische und politische Schweiz". In: id.: Die tintenblauen Eidgenossen. Über die literarische und politische Schweiz. München: Hanser, 9-78. 
Nairn, Richard (2007): Ireland's Coastline. Exploring its Nature and Heritage. Cork: Collins Press.

Nizon, Paul (1970): „Diskurs in der Enge“. In: id.: Diskurs in der Enge. Verweigerers Steckbrief. Schweizer Passagen. Frankfurt a. M.: Suhrkamp, 1990, 137-226.

Oehlke, Andreas (1992): Irland und die Iren in deutschen Reisebeschreibungen des 18. und 19. J ahrhunderts. Frankfurt a. M. u. a.: Lang.

Pfister, Eva (2008): „Schätze finden, Unfälle bauen“. In: Die Wochenzeitung 85, 5. 6. 2008, 38.

Rausch, Tina (2009): „Interview mit Rolf Lappert“. In: dtv-Magazin, 10. 12. 2009, o. S., http:/ / www.magazin.dtv.de/index.php/ 2009/ 12/ 10/ rolf-lappert-2 (retrieved 4. 5. 2010).

Reich-Ranicki, Marcel (1963): Deutsche Literatur in West und Ost - Prosa seit 1945. München: Piper.

Reinacher, Pia (2003): Je Suisse. Zur aktuellen Lage der Schweizer Literatur. München/Wien: Nagel \& Kimche.

Richard, Christine (2008): „Im Schatten der Sonnenschaukel“. In: Basler Zeitung 32, 7. 2. 2008, S. 4-5.

Rossum, Walter van (2008): „Der Vorhang der Pupille“. In: Die Zeit 29, 10. 7. 2008, 48.

Sabalius, Romey (1997): „Das Bild der USA in der zeitgenössischen Literatur der deutschsprachigen Schweiz". In: id. (ed.): Neue Perspektiven der deutschsprachigenLiteratur in der Schweiz. Amsterdam: Rodopi (= Amsterdamer Beiträge zur neueren Germanistik 40), 11-30.

Schnauber, Cornelius/Sabalius, Romey/ Stimpson, Gene, eds. (1995): The Dream Never Becomes Reality. 24 Swiss Writers Challenge the United States. Lanham/New York/ London: UP of America.

Schnauber, Cornelius/Schulte, Hans (1995): „Introduction“. In: Schnauber/ Sabalius/Stimpson (1995), vii- xiv.

Spiegel, Hubert (2000): „Erdmännchenblicke“. In: Frankfurter Allgemeine Zeitung $42,19.2 .2000, \mathrm{v}$.

Steiner, Tabea (2009): „Der erste Schweizer Buchpreis“. In: ensuite - kulturmagazin $73,7$. 